\title{
Is the woman in the Song of Songs really that
}

\author{
free? ${ }^{1}$
}

\author{
S S Ndoga \& H Viviers \\ Department of Biblical and Religious Studies \\ Rand Afrikaans University
}

\begin{abstract}
The Song of Songs has often been treated as a platform for feminist liberationist causes. This study aims to re-examine some feminist ideological readings of the Song of Songs. Although feminist scholars insist that the female "voice" is very conspicuous in the Song, the male voice is also constantly "there" and equally strong. Thus, the Song does not celebrate the supremacy of either gender, but praises mutuality and equality. As analysis of a sample text, 1:2-4, is carried out, using a "newcomer" approach (at least to Old Testament studies), namely sociorhetorical criticism. This approach allows an integrated scientific approach to the reading and rereading of texts from various angles. Ideological questions come into focus, such as: What exactly does an ideology involve or imply? Whose ideological reading is the best reading of the text? Is there such a thing as a best reading of a text? Does the Song of Songs itself prescribe a particular ideological reading? Finally, applications and principles as derived from the exegetical findings are summarised to encourage a wider readership and use for the Song of Songs.
\end{abstract}

\section{INTRODUCTION}

A new trend in biblical studies is a move away from author-and text-centred readings which presumably exclude readerly interests from the interpretational process. ${ }^{2}$ It is now

\footnotetext{
This article is based on an MA Thesis completed in the Department of Biblical and Religious Studies at the Rand Afrikaans University (supervisor Prof $H$ Viviers).

${ }^{2}$ Clines (1990:9-12) describes an author-centered approach as a way of speaking of what the given passage originally meant, using a historical-critical method, while the text-centered approach refers to what the passage currently means by studying the literary features of the work as a whole. Reader-centered approaches flourish on ideological readings such as those that are the focus of this study, with particular reference to feminist hermeneutical perspectives and the resulting praxis.
} 
acknowledged that an "interaction between the world created by the text, the world of the author and the world of the interpreter represents the environment in which meaning is created" (Robbins 1996a:40; italics mine). A prioritising of the world of the reader as involved by Postmodern Biblical Criticism has stimulated, inter alia, feminist ideological readings that endeavour to develop political criticism of the Bible. ${ }^{3}$

Feminist readings specifically oppose the patriarchy, under which biblical scholarship has been traditionally conducted, and duly attempt to expose patriarchal assumptions. The Hebrew Bible is also a product of a dominant (male) culture. This means that feminists feel that they need to provide alternative approaches targeted at creating "meaning" in and of biblical texts. Consequently, gender inclusiveness has been one of the formal issues of feminist criticism. ${ }^{4}$ This article presents an outsider's critique of some feminist ideological readings from a socio-rhetorical perspective. Excellent feminist studies have been done on the Song of Songs. It does seem, however, that sometimes the feminist case may have been overstated.

Perhaps, the heart of feminist biblical scholarship is the preposition that the Bible, when properly analysed, yields emancipatory interpretation. This argument is shared by two groups: firstly, Reformist Readers (readers who attempt to restore images of women in the Bible), and, secondly, Revisionist Readers (readers who argue that patriarchy is historically and not theologically determined). ${ }^{5}$ A third category of feminist scholarship,

\footnotetext{
${ }^{3}$ Pieterse (1996) reflects on the manner in which non-biblical ideologies, such as Marxism, Feminism and Environmentalism, continue to influence textual analysis. The various ideological hypotheses attest to the truth of the maxim that there is no innocent reading of the Bible.
}

4 Lemer (1986:232) defends the case for gender inclusiveness by saying that "words are socially created cultural constructs, they cannot come to life unless they represent concepts accepted by large numbers of people". Such concerns lead to the introduction of the highly controversial work sponsored by the National Council of Churches issued under the title Inclusive Language Lectionary (see Sakenfeld 1988:16), as well as the introduction of terms such as "Goddess", "God/ess" or Schussler-Fiorenza's acronym "G-d" (1983:175). No matter how many terms have been proposed, feminist scholars themselves have found these terms wanting.

3 The stipulated categories of feminist hermeneutical perspectives are not intended to be exhaustive, nor should they be regarded rigidly, since they tend to overlap. The Reformist category, in this study, includes Aichele, et al's "Hermeneutic of Recuperation" and "Survival" $(1995: 245,251)$. The former attempts to restore images of women in the Bible via the retrieval of strong foremothers, role models and characters with whom contemporary women might identify. The latter focuses on social and political institutions of domination, with especially African-American women acting as advocates of such readings. In both cases, the image of women is a matter of primary concern, hence the rubric Reformist readings. However, Reformist and Revisionist readings form part of a loyalist perspective, where, although the view of biblical authority varies among scholars, biblical authority's centrality in theological pursuits is retained. 
the Rejectionist Readers, alleges that the Bible is hopelessly irredeemable from its androcentrism, so that the only option is to construct a world for women by women alone. $^{6}$

While androcentric bias within the Hebrew Bible remains a complex issue, some feminist scholars attempt to combine reformist and revisionist stances in their readings to rethink such difficulties. One such scholar is Phyllis Trible, who suggests a counterexegesis that unveils what she calls God's intention in texts. She writes (1987:1):

Some studies document the case against women in the Bible evaluating evidence for their inferiority, subordination and abuse. Others explore within scripture itself a counter-literature pertaining to women that stands over and against the dominant patriarchal biases. The creation texts in Genesis 1-3 and the Song of Songs provide such a view as does female imagery for God.

In this study, the Song of Songs is selected to explore whether or not the text specifically downplays a masculine orientation and thus upholds a feminine and feminist voice. Such an interpretation is in line with the ideological ethos that seeks to produce counterreadings, as Adam (1995:54) aptly suggests:

\begin{abstract}
Postmodern ideological critics will continue to point out the ways that the dominant social groups' approaches to the Bible produce and reproduce oppressive social relations, but they will also produce counterreadings that rest not upon better research and more objective analysis - thus leaving intact that apparatus with which our dominant culture produces its oppressive readings -
\end{abstract}

\footnotetext{
${ }^{6}$ Mary Daly is the most outspoken of the revolutionary scholars who write against the Judaeo-Christian tradition as being intrinsically biased in favour of males and therefore to be rejected (see Keane 1988:133). Osiek (1985:98) describes the futility of efforts by scholars like Daly, arguing that their major weakness is total rootlessness, cut off from the historical past and from much of the historical and social present. The present study does not examine Rejectionist theories any further since the principal interest of this article remains feminist ideological readings which still employ the Bible as a text and source for the praxis of theology.
} 
but on the alternate approaches to interpretation, approaches that more closely reflect the local truths for which ideological critics stand. ${ }^{7}$

The stance taken by ideological critics in general translates itself rather aggressively to shape their hermeneutical perspectives by challenging "traditional interpretations that claim universality, completeness and supremacy over other interpretations to show that these interpretations are themselves enactments of domination or, in simpler terms, power plays" (Aichele et al 1995:2).

To verify with some precision what the implications of feminists ideological readings are, this article briefly explores their criticism of traditional readings of the Song, then engages their ideological interests in the Song itself, before finally evaluating their exegetical findings on Song of Songs 1:2-4 from a socio-rhetorical stance. The choice of this pericope merely serves to demonstrate exegetical findings that recur throughout the Song, findings that essentially validate the thesis that: while feminist scholars insist that the female "voice" is very conspicuous in the Song, the male voice is also constantly "there" and equally strong. It is also for this reason that the title of this article was formulated as a rhetorical question, implying that the woman is not as free as some readers would want her to be. It is commonly acknowledged that man and woman are "tête-à-tête"-in the Song. Their intimate dialogue throughout confirms this. It has also been noticed that the woman speaks more often than the man. This, however, does not elevate her to a status of total freedom. Her "freedom" is constrained by her relationship with the man of her choice.

\footnotetext{
7 "Ideology", as Clines (1995:10) confirms, is a notoriously difficult concept to explicate. Clines himself lists seventeen descriptions of the concept according to what he calls denotations and connotations, although he chooses to operate with only two of these; a relatively coherent set of ideas amounting to a world-view, or outlook on life; a set of ideas special to a particular social class or gmoup. Lochhead (1993:28) offers a very helpful and concise definition; "Ideology refers to the social economic, cultural and political dimensions of one's point of view". For the purposes of this article, the concept denotes readerly. interests, namely prejudices, presuppositions and concerns that readers bring with them when they approach biblical material.
} 


\section{CRITICISM OF TRADITIONAL READINGS OF THE SONG OF SONGS}

The exegetical questions and debates concerning the Song of Songs are marked by the way in which scholars have presented various theories in an attempt to justify their views one way or another. Many of these scholars are guilty of selecting only elements that support their notions ignoring and excluding any elements that contradict or even demolish their interpretations (Bakon 1994:211). Traditionally, scholars' contentions have centred around three approaches, namely allegorical-typological, cultic-mythological and literary theories (Mazor 1997:1). At present, feminist scholars contend that these (patriarchal) traditional readings neglect the dominant portrait of the woman in the Song, who seems to be both the subject and initiator of all that ensues in the Song. Feminist approaches suggest the need for a "reader response criticism", that is, a reading strategy described as follows: "This movement holds that the preoccupation with authorial or 'historical meaning' or even 'canonical context' is superfluous, and despite a more mature approach which places the emphasis on 'intersubjectivity'... any interpretation still begins with the reader" (Elliot 1994:138).

Placing the emphasis on the reader paves the way for feminist scholars to obtain a hunting ground for emancipatory causes by promoting an ideological reading that focuses primarily on the unusual cultural paradigm suggested by the role that the woman in the Song plays, especially in what is predominantly a patriarchal context. This is an area that needs to be examined more closely.

\subsection{An allegorical-typological reading of the Song}

An allegorical-typological approach, a conventional basis for the canonisation of the Song of Songs, recommends itself to both talmudic sages ${ }^{8}$ and Christian exegetes of a typological reading of the relationship between God and his people. The allegorical

\footnotetext{
8 Broyde's (1995:66) article, which explores certain quarters and various aspects of Talmudic literature where doubts are still expressed with regard to the canonical status of the Song among other books, describes the criteria for canonical status as follows: "Defiling hands is a status of ritual purity (or impurity) that is completely rabbinic in nature and was enacted by the Talmudic sages not to promote ritual purity, but to protect holy works from destruction or desecration". The difficulty of including the Song among the sacred texts rests on the absence of the Tetragrammaton - the explicit absence of the mention of God, a factor ignored by most (male) commentators, according to Blumenthal (1995:87).
} 
approach developed chiefly to counter a reading of the Song as a purely secular love song among the sacred texts, hence the downplaying of the literal sense of the Song in favour of a hidden meaning. In this regard, Richardson (1994:135) makes a valid observation:

"When the Song of Songs was seen as a depiction of the soul's longing for God, it was relatively straightforward for mystics like Bernard of Clairvaux to preach from it without the embarrassment because they did not have to engage with the plain terminology about the thighs and the breasts."

While such an allegorical reading retains the sympathy among some scholars, the main criticism against susch an approach is that the "Song is in danger of becoming a code to be cracked, a means to an end, for vivid imagery of the Song tends to be subordinated to the general interpretation in the light of which the Song as an imaginative ensemble fades from view" (Munro 1995:12). ${ }^{10}$ However, since the Song operates on aspects of midrash, a concept that encompasses "to ask, to explain, to draw out, to enlarge upon - spaces in the text [which] set the scholars to dreaming and to imagining answers to their own questions" (Rosen 1996:421), these aspects provide much grist for feminist treatment, adding substance to a feminist approach. However, a non-allegorisation of the Song, in its turn, can aid feminist causes in that "where God is not, [it] is as much a function of the reader as it is of the text" (Blumenthal 1995:89), to recall the primacy placed upon the world of the (feminist) reader.

\footnotetext{
9 An example of the resultant allegorical reading can be highlighted in a reading of Song of Songs 1:13: My lover is a sachet of myrrh resting between my breasts. "Breasts" are read as symbols for the Old and New Testaments, while the sachet of myrrh represents Christ who rests between both the Testaments (cited in Dillard \& Longman III 1995:260). It remains unclear as to how the correspondence between the imagery and the symbols is decided.

10 Moye (1990:21) asks whether it is possible to move from a literal level of meaning to a mystical level without violating the text, but he is the first to admit that such a move is complex. Similarly, Richardson (1994:135-142) suggests a refinement of methods akin to allegory, basing his hypothesis on the fact that naturalistic readings, while faithful to the text, have made applicational questions difficult to resolve. Stadelmann (1993) presents a unique position in that he reads the Song as a tactical stance by the composer to disguise Jewish nationalism from Persian authorities, since the Song is, to him, a post-exilic product addressing unity. However, in most cases where typology is reminiscent in a given biblical passage, the text itself internally prescribes to the reader a move from an analysis of allegory to its application. Examples of such a stance include Hosea 1-3, Jeremiah 2-3, Isaiah 50:1, 54:4-8 and Ezekiel 16:23. In these instances, the text internally controls the symbolism, thus preempting the reader's subjectivity, and this suggests a tactical stance unlikely in the allegorical reading of the Song of Songs. In addition to that, the cited examples present their material in negative terms, as opposed to the positive relationship presented in the Song.
} 


\subsection{A cultic-mythological reading of the Song}

The cultic-mythological approach developed out of recent studies of comparative literature for the ancient Near East which postulate that the Song of Songs is actually a commemoration of a sacred marriage of a Canaanite god and goddess whose union restores favourable demographic conditions." According to this line of thought, the Song in its current form represents a Hebrew adaptation of a text of pagan origin in its literary form, poetic techniques, motifs, themes and eroticism, (one such study is that by Watson (1995:253-271)).

The assumption today that all Hebrew love poetry was admitted without further ado from pagan cultures into Israelite religion and automatically into its canon can only be adopted with some reservations (Kinlaw 1991:1205). Commonality in the material contained in various texts produced by ancient Near East communities is admittedly evidence of the intercultural exchanges characteristic of that period; ${ }^{12}$ even so, there seems to be a deliberate absence of cultic language in the Song, perhaps to distinguish it from the love poetry of the ancient Near East.

However, in terms of a feminist agenda, reading the Song from a cultic-mythological perspective allows neglected issues to be examined. There is archeological evidence that certain cultic practices flourished among Israelite women. These women were better informed in low-cult activities than their male counterparts who were inevitably absorbed in high-cult Yahwist interests. Denver (1991:65) comments:

In ancient Israel, the Deuteronomists obviously opposed the cult of Asherah out of Yahwist zeal. In part this was because the religious establishment was exclusively in the hands of males. As feminist scholars in particular have

\footnotetext{
"Pope's commentary (1977) lends itself strongly to this reading. He focuses on imagery with a particular purpose to find clues that may link his findings with cultic practices within the ancient world. Sasson (1979:184) presents a different reading, arguing that the constant allusions to Canaanite, Egyptian and Mesopotamian mythologies are in themselves but variant forms of allegory.

${ }^{12}$ See Fox's (1985) well-informed comparison of the Song and Egyptian love poetry, Mariaslaven's (1988) study which focuses on the relationship of the Song and Tamil love poetry, Jinbachian (1997) who explores similarities between love poetry in the Song and the Arabian Odes and Watson's (1995) comprehensive study of the generic ancient parallels to the Song. The present authors' observation in most of these comparative studies is that, while the findings are helpful, the observed points of commonality are overstressed, so that one learns more about cultic mythologies than about the Song itself.
} 
pointed out, however, males seem to have been preoccupied with the public aspects of religion .... Females on the other hand - in part because they were excluded from participation in much of public life - tended to be concerned with household rites, local shrines and saints, private rituals involving other women and especially with all those connected with bearing and raising children. $^{13}$

Following this line of argument, Watson (1995:254) suggests that the writing of love poetry was chiefly a feminine occupation, supporting the possibility of female authorship for the Song.

\subsection{A natural reading of the Song}

A literal approach is not a new reading of the Song. Theodore of Mopsuestia interpreted the Song in this way as early as AD 429 (Schneekloth 1977:18), ${ }^{14}$ but his views were condemned by the church (after his death) as "unfit for Christian ears".

"Rhapsody" is perhaps the most appropriate epithet that can be used to capture the ethos of the Song, of the outpouring of the uncontrollable emotions of the lovers. Webb (1990:92) expresses the idea as follows:

There is an intimacy about the book which is both delightful and embarrassing. The lovers are not aware of our presence. What they do they do to one another and not to us. In a sense, the book is not addressed to us at all - and

\footnotetext{
13 See also Meyers (1978), who traces the historical context out of which Israel emerged, a context in which feminine deities were popular, and Goitein (1988) whose study of Yemenite communities shows that the creation and performance of poetry was basically a feminine task.

14 There are two schools of thought based on the naturalist approach. The first perceives the Song as drama in poetic form, as championed by Goulder (1986), who plots the Song into fourteen scenes that proceed from the royal palace leading to an imaginable consummation of the relationship (cf Delitzsch 1885; Dennison 1993). There is no agreement among these scholars regarding the plot, scenes or characters in the Song. The second school of thought cites parallel texts such as Psalm 45, Proverbs 5-7 and 31:10-31, to mention but a few examples, of the plain treatment of human sexuality. See Schroeder's article (1996) on Psalm 45, in which he observes that much attention in previous studies has been paid to the historical context of the Song, but that its interpretation as a theological document has often been neglected. This attitude perhaps illustrates the persisting hesitancy among scholars to deal with the plain sexuality that the text portrays.
} 
yet it is, for by simply being there for us to read it opens a window for us to experience in some measure what the lovers themselves are experiencing.

The reading strategy outlined above is utilised to promote the conviction that "reading as a (feminist) woman is dedicated to redressing the balance in the traditional comprehension of literary discourse, the world created by the text, and to transporting those realities into a world that the feminist convictions espouse" (Brenner 1993b:21). The exercise described by Brenner is directly applied to the reading of the Song of Songs which characteristically yields features of particular interest to feminist readers. In effect, natural readings could advance the feminine bias perceived to dominate the Song. In that regard, Brenner insists that the Song displays a female bias in view of the sum total of speech acts assigned to the woman; the constant references to appearance of the daughters of Jerusalem; the preference of the mother's house as opposed to the father's; and the deliberate absence of the fatherly figure in a typical patriarchal context.

To summarize, the criticisms outlined above of traditional readings of the Song of Songs by feminist scholars in some ways promote a female agenda in such interpretations of the Song. Nevertheless, whether the Song is treated in an allegorical-typological, cultic-mythological or natural manner, important possibilities for feminist readings are neglected. "Gaps" in the text tend to be filled by male-biased scholarly solutions. The possible female authorship, the strong female voice throughout, the liberated "female world" created by the text (as opposed to typical women's roles such as child-rearing, domestic duties, etc) and non-sexism in the Song have not always received deserved attention. The liberated "female world" resulting from a natural reading can, however, be over-emphasized as though men in the world of the poem are totally irrelevant. Such an emphasis has to be reassessed.

\section{A SOCIO-RHETORICAL READING OF SONG OF SONGS 1:2-4}

Polaski (1997:64) observes that in the last three decades, many feminist biblical scholars have advanced the notion that the Song of Songs preserves the rare platform in the Hebrew Bible where women speak with an authentic, liberated voice. Such (one-sided?) 
feminist ideological treatments of the text seem to want to prove this point at all costs, perhaps at the exclusion of other equally valid critical reading incentives. The question to ask at this point is whether the ideological texture of a text ought to be treated as the sole basis for determining the meaning of a given text. This study adopts a reading strategy that seeks to demonstrate that the ideological texture cannot be treated in isolation, but belongs to a wider scope of textures, namely inner, inter, social and cultural and sacred textures, all of which come into play in the exegetical analysis demonstrated below (Robbins 1996b).

\subsection{Reading strategy}

The choice of Robbins' socio-rhetorical approach is of cardinal importance for this explication of the Song as well as for an evaluation of some feminist reading strategies. Robbins' approach represents perhaps the most successful attempt to amalgamate various scientific reading strategies under a single rubric. It focuses on literary, socio-cultural and ideological issues in texts as nuances intended to "develop strategies of analysis and interpretations that exhibit the multiple network of meanings and meaning effects that the words in our texts represent, engage, evoke and ignite" (1996a:9). By so doing, the approach brings specialised knowledge into the dialogue and creates a context for generating new insights, new ideas for research and new specialist areas that lead to a new account of textual analysis.

Most (feminist) scholars agree that a close reading of the text ought to be done to allow sufficient attention to be given to the stylistic and rhetorical devices in the Song itself (see Exum 1973:47). The most noticeable feature of the Song is that the narrator's voice is barely detectable. Instead, the textual figures, who are neither introduced nor narrated, control the discourse by presenting their own case(s) (Brenner 1993c:266-7). For feminist scholars, the starting point to a "true meaning" of the Song should be the recognition that the Song is feminine at heart, the tale of a woman, telling her story, her plight, her yearnings, her strengths and frailty, her oppression and flight to freedom (McMonagle 1995:3). But is that all that we can read in the Song? 


\subsection{Request for Love 1:2-4}

Opening Poem 1:2-4

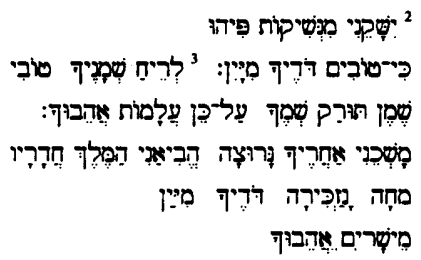

It has been stated above that Song 1:2-4 is utilized in this article as a sample text. It forms a close-knit unit, clearly demarcated from the superscription 1:1 and the ensuing self-description of the woman in 1:5-6. But why choose this pericope? It is wellknown that the ancient rhetoricians emphasized the opening words (and the close) of a speaker/ writer as extremely important in the art of persuasion. Not only are first impressions often lasting ones but the listener/reader gets a glimpse into the "heart" (values, convictions, etc) of the orator. It therefore seems worthwhile to pay close attention to the opening words of the woman, so as to grasp something of the "ideology" of the Song right from the start.

Song 1:2-4 opens with a female speaker who seems to be the initiator of all that ensues. Brenner (1993b:75) even singles out this pericope among others as being so essentially feminine that a man could hardly imitate its tone and texture successfully. The woman in the Song plays a role that, presumably, provides a paradigm for contemporary women to recover a heritage of feminine prominence and independence. She utters the longing of her heart, "Let him kiss me with the kisses of his mouth" (NIV), a wish, one notes, expressed through a commanding voice (Falk 1990:167). But what is it that she commands?

To answer that question, we need to explore the connotation(s) and meaning of the phrase "kisses of his mouth". Robbins' method invites those who apply the method to engage the various textures of reading and rereading the text from various angles, as pointed out earlier. A good way to start, although it is not the only way, is to focus on what is inside the text and then to move to what is outside the text (Robbins 1996b:5). With regard to the inner texture, which investigates the "relationship among word-phrase 
and narrational patterns that produce the argumentative and aesthetic patterns in the text" (Robbins 1996a:46), the first stanza does not contain a predominance of particular words or phrases, nor does the rest of the unit. However, specialised repetition and other rhetorical devices articulate the repetitive-progressive pattern and other complementary sub-textures, to shed some light on the meaning of the text. The narrational pattern (Robbins 1996a:53) obviously resides in the supposedly female speaker who, in her soliloquy, alerts the reader, without delay, to the intimacy she longs for with her lover. ${ }^{\text {is }}$ The Hebrew concept "let him kiss me" may be onomatopoeic (the use of sound imitation to intensify the imagery), thus lending substance to the bare words by making them sound like the actions they describe (Watson 1984:230). Already we can establish that the discourse pre-empts qualitative arguments, since the reasoning is not necessarily persuasive in function (Robbins 1996b:16). The kisses that are being sought, иT "with the kisses of his mouth", reflect strong desire, appropriate in view of the tenor of the rest of the Song (Murphy 1990:127). The concept itself is not instrumental, but partitive, as can be established from the use of the preposition jo. To capture the resonant passion in that request, the opening phrase should preferably be read, $O$ that he would kiss me with kisses of his mouth. ${ }^{16}$ The actual intent of this request is furnished by the stated reason for his being so desirable - for his love is better than wine. The concept in the plural form, רדי, "your loves", repeated in 1:4, appears to indicate lovemaking as the actual object of pursuit here, since it renders the idea of caresses. In fact, the participle ?. "for", has an emphatic function that boosts the intended effect. The adjective "better", repeated in 1:3 with a different subject, further qualifies the desired love in the sense that the kisses are, by far, better than the pleasure one gets from wine. Incidentally, the association of love and wine is common in the Song $(2: 4 ; 4: 10 ; 5: 1 ; 7: 10$ and $8: 2)$. It

\footnotetext{
is In this study, the designation of the male character as 'lover', or the female as the 'beloved', does not in any way imply the gender stereotypes usually associated with these concepts in their traditional application. By the same token, some feminist scholars prefer the reverse onder which speaks of the woman as the lover and the man as the beloved to go with their ideological articulation of the woman in the Song as the initiator of the relationship, thereby playing a paradigmatic role for contemporary women to emulate.

16 The translation adopted here merely attempts to invest the English equivalent with the passion contained in the Hebrew expression. By so doing, one digresses a little from the Hebrew subject pronoun which means that the line literally reads, Let him kiss me with the kisses of his mouth. See also Fox (1985), McMonagle (1995) and Munro (1995), who favour the proposed reading. Note as well that the verb forms and pronominal suffixes shift from third to second person, a grammatical shift characteristic of biblical style (Falk 1990:166).
} 
evokes the sensory-aesthetic texture (Robbins 1996b:22), particularly the sense of taste, since the adjective טמר in relation to wine can also mean "sweeter" (Murphy 1990:125).

The occurrence of 0 at the beginning of $1: 2 \mathrm{~b}$ and at the end of $1: 3 \mathrm{a}$ creates the outer cores of a chiasmus, while "your love" and "your oils" form the inner cores. The chiasmus reveals a correspondence in the strophe which validates his desirability, which remains the focus of the pericope (1:2b-4). The adjective in 1:3 stresses the idea of "pleasing" in the description of his scent or fragrance, which is the subject of appraisal in 1:3-4, 12-14 and also the central theme in 4:1-10.

There is sound play on the words at, "name" and "oils", and repetition by means of anadiplosis (Watson $1984: 208-13$ ). The sound play on the words cannot be reproduced in the translator language. The association of the two concepts here functions as a synonym for reknown and coronation to enhance the portrayed figures of speech. In that regard, Falk (1990:165) comments:

... the image may have a more abstract meaning; names may be said to be like smells in their ability to mark and thus evoke, individual identity. A sweetly fragrant name might be one that pleasantly calls to mind its bearer, much as a whiff of familiar perfume can do. Whether uttered only as called to mind, the name of the beloved has powerful sensual impact on the speaker of this line. The line is further emphasised in the Hebrew by its semantic alliteration semen turaq šmekha.

Falk's statement underscores the sensory-aesthetic texture constantly deployed in the text, particularly the sense of smell. Pilch (1996:249) points out the observation of modern science that memories evoked by smells are usually more pleasant than those evoked by visual or oral cues.

Consequently, the image he commands. Thus, the conjunction "therefore", moves towards the culmination of the pericope by illustrating that womenfolk commonly admire. The concept פיפליס. "maidens", without the definite article, could speak of the women identified in the Song as the daughters of Jerusalem or simply unmarried young women (1:5; $2: 2,7 ; 3: 5,10 ; 5: 8,16 ; 6: 9 ; 8: 4)$. 
The second strophe (1:4) reiterates the desire through the consequential imperative משָשכנים, "draw me", indicative of the woman's intense emotion and the urgency of the plea she makes: מֶֶּ, "let us hurry" (NIV). The sudden appearance of "king" sounds out of place. The royal epithet explicitly accorded here is common in the Song (1:12), a feature that a number of commentators regard as hyperbole or royal fiction. The text "crowns" the admiration the male commonly excites and the coronation alluded to in $1: 3$ through the description of ointments that befit a royal figure. The female speaker evokes the sensory-aesthetic texture once again, demonstrating that "scents communicate more than the simple words express" (Pilch 1996:248). Whether the ointments she describes are factual or fictitious is immaterial. She knows the scents she describes and rightly associates them with the man she loves. The anticipation also alludes to "sight" in the reminiscence of the respect due to the king. It becomes apparent in subsequent pericopes that the lover is portrayed as other figures who fluctuate specifically in line with the mood depicted. A sense of privacy is sought, since the term "his chambers" (note the plural form), describes the innermost seclusion of the man's house. The urgency in 1:4a may require $1: 4 \mathrm{~b}$ to be read vocatively, "Bring me into your chambers" (NEB), although most translations prefer the declarative form to actualise the important element of privacy: "The King has brought me to his chambers" (Murphy 1990:124). A similar impatience is echoed in 8:1-4.

The shift to the first person plural in 1:4c-d is probably emblematic of the implied admiration of this man by womenfolk, although the term (the upright?) is problematic. Stadelmann (1993:24) connects it to †. "they love you". It also occurs at the end of $1: 3$, where it is governed by the undefined subject "maidens" to reiterate how satisfactory his "lovemaking" is, thus concluding the pericope as it commenced.

A text does not originate or exist in a vacuum. Even though a lot of "meaning" surfaces when one gets "inside a text" by focusing on inner texture (Robbins 1996b:7), a text also draws "meaning" from the "world" outside. It interacts with intertexts such as objects, oral/scribal texts, customs, values and so on (1996b:40). An intertextural analysis comprises an analysis that appropriates and refigures source, form and redaction criticism in biblical texts (Robbins 1996b:47). For a fuller appreciation of the kisses the woman commands, intertexture is therefore a helpful tool. Fox (1985:97) reminds 
readers that the Hebrew concept "kisses of the mouth" is not pleonastic, since not all kisses are with the mouth. A gesture of affection frequently used in the ancient Near East was the nose kiss, when a couple would rub noses. Here, however, the woman does not ask for a nose kiss. Gledhill (1994:94) recapitulates rather graphically the intended gesture in the following words:

[It is not] just a formal peck on the cheek from cold passionless lips. She wants to feel his mouth's deep kiss inside her own, and to know his fond embrace ... . She is very tactile. She wants to be touched and to be held, not just as an object of his desire, but because she wants to be stirred to give herself to the one whom she loves.

With regard to "love", Proverbs 7:18 supplies a biblical intertexture from which it is clear that to speak of harlotrous couching is to speak of an act devoid of true love (Fox 1985:97). In fact, Proverbs 5-7 offers a parallel (an analogy) for wisdom collectors who offer a monogamous ideal that ought to be understood as the basis for a perennial love relationship (Holder 1994:550).

Enhancing the "meaning" of the chosen pericope even further, the application of insights from sociological and anthropological theory as applied to the ancient Mediterranean world is very fruitful. Robbins (1996b:57) refers to such a procedure as the social and cultural texture of a text. As soons as the reader utilizes this texture, a rather dependent woman is immediately foregrounded. It questions feminist ideological readings that insist on the total independence of the woman in the Song. We meet this woman as a dyadic personality (Robbins 1996b:77-78) - one who needs another person in order to know who she really is. The pericope is epitomised by her fugue of appraisal of the man whom she deeply desires. While it is true that the pericope is marked by the commanding feminine voice, the author does not overlook the masculine role at all. The woman longs for the man, she needs him to "constitute" her (Polaski 1997:71). The thrust of the ideology of power in the discourse of the text (Robbins 1996b:85) does not attempt to institutionalise power, nor to rationalise power relations. For the implied author, a system of differentiation is immaterial, since the mutuality of the female speaker and the implied male lover seems to be the focus. It must be said that the text 
resists attempts to project domination or subordination, but stresses the values of mutuality and equality. This is the image of the implied author throughout the Song.

It is difficult to ascribe a specific context to the Song. Clines (1994:8) is of the opinion that the Song arose out of a competition among males to come up with the best composition; in other words, it was written by a male presenting love "through a woman's eyes". The Song in its present form represents the winning composition. Brenner (1993c:174) relies on parallel Egyptian and Tamil love poetry to advocate a freedom that is evidently allowed to women in this genre but denied them in other life situations. Falk (1990) identifies a variety of contextual shifts in the Song, which function to reflect the portrayed moods and intended effect. The present authors suggest that the lexical allusion to Solomon $(1: 1,6 ; 3: 7-11 ; 8: 11-12)$ functions to set the Song in the Solomonic era - a patriarchal context. If one makes that assumption, then, this suggests that the implied author offers an alternative relationship ideal, namely equality and mutuality of the sexes, by means of a gnostic-manipulationist text.

It goes without saying, therefore, that the woman speaker desires a physical encounter (sex?) with her partner. She issues the request, as noted above, with a commanding voice, which is not necessarily suggestive of superiority (à la extremist feminist readings). The pericope is sustained by her reiterated desire for his companion-ship, which in essence depicts her dependence upon the man for the fulfilment of her deepest wish.

\section{CONCLUSION}

The values of equality and mutuality seem to be dominant ideas in the Song. In that sense, this reading of the Song departs from the notion that the Song seems to preserve a rare platform solely for women to be heard, a feminist reading that inevitably yields emancipatory consequences. The Song does not provide enough evidence to back up the notion that it should be interpreted as a relatively undamaged product of Israelite women's culture, as Brenner (1993a:257) attempts to prove when she writes:

It is conceivable that the SoS was dramatised and sung to a bride inside her mother's compound just before she was led to her groom, when women 
played the roles of all parties mentioned, including the male roles. Such a hypothesis would satisfactorily explain quite a few aspects of the SoS - the female voices' boldness, the frequent mentioning of the mother's home, the female predominance, the freedom of speech implausible in mixed company. It would also explain the daring sexual humour attributed to a male voice, through the knowing filter of a woman's perception and dramatisation - like a play within a play, a parody within a parody.

We see in the first place that the woman speaks with a commanding voice to request the man's kisses and to accord him respect by using the royal fiction. In the second place, we are made aware that the kind of kisses she commands at this point would be reserved for an intimate couple. In the third place, we realise that the woman in the Song in her soliloquy projects a dyadic personality and by so doing exalts the man, at least to a position of equality, as the one who satisfies her deepest needs. Thus the Song functions to provide an alternative relationship ideal between the sexes, bearing in mind that the "real world" cultural context was patriarchal.

While the man does not speak at all in the analysed pericope (although he does so subsequently), his voice is assumed via the attention he commands. Given that detail, this study cannot agree with the extremist feminist position that attempts to see the feminine voice as almost exclusive. As Polaski (1997:81) aptly says: "While the female figure is the subject of the Song, this status does not mean that the Song must be heard as liberating for women. Indeed, just the opposite may be true". In this study, the authors support Falk's observation. She (1990:118) dismisses a count of the sum total of speeches as decisive in the matter of power:

The speech of men in the Song, even if limited to fewer modes (and somewhat fewer lines) than that of women, also seems true - that is, not filtered through women's imaginations, but rather authentically self expressive. Indeed I would argue that men's speech in the Song is as authentic as women's, despite - or actually, because of - the overwhelming linguistic similarity between the two. The rich, sensual, emotionally expressive, and often playful language of the Song's female and male voices (whether they are speaking directly or 
indirectly, to others or to themselves) seems to evidence a non-sexist, nonhierarchical culture - unique in the Bible.

These words of Falk also neatly confirm the thesis stated at the beginning. The man's voice and presence is just as much part of the Song as the woman's, even though the woman speaks more often and more daringly than expected in a patriarchal culture. Although the scale tips in favour of the woman in terms of the quantity of speeches in the dialogue between her and the man, this does not imply her full emancipation. She needs the man and he needs her. The Song stresses mutual dependence, not an immature anchorage in each other, but a life-giving "symbiosis" for each to bring out the best in the other.

The Song of Songs clearly has a message directly applicable to our modern context of androcentric realities, in that it attempts to find a balance. The Song is not about power or position. While it rejects patriarchal domination through the strong role that the woman in the Song plays, it equally downplays matrilineal domination. The answer to the rhetorical question of the title of this article, "Is the woman ... really that free?" is clearly a "no!" if freedom is meant to reflect a hunger for power. It is also interesting to note that "male input" is welcome nowadays in some feminist circles, where as this was previously not the case. It is significant to discover in the Song that it is the man who gives meaning and identity to the woman by not subjecting her to the then accepted inferior position of women. These are the kinds of men modern (patriarchal) societies need. Perhaps Payne (1996) got it right by reading the Song of Songs as the Song of woman, the Song of man and the Song of God in harmony. This article suggests that the ideology of the writer of the Song is intended to lead the reader to a similar conclusion.

\section{Works consulted}

Adam, A K M 1995. What is Postmodern Biblical Criticism? Minneapolis: Fortress. Aichele, G et al 1995. The Postmodern Bible. New Haven: Yale University Press. Bakon, J 1994. The Song of Songs: An Enigma. JBQ 10(1), 8-15. 
Blumenthal, D R 1995. Where God is not: The Book of Esther and the Song of Songs. Jud 44 (1), 80-92.

Brenner, A 1993a. A Feminist Companion to the Song of Songs. Sheffield: Sheffield Academic Press.

- 1993b. On Reading the Hebrew Bible as a Feminist Woman: An Introduction to the Series, in Brenner, A (ed), A Feminist Companion to the Song of Songs, 12-23. Sheffield: Sheffield Academic Press.

- 1993c. To See is to Assume: Whose Love is Celebrated in the Song of Songs. BInt 1(3), 265-84.

Broyde, M S 1995. Defilement of the Hands, Canonisation of the Bible, and the Special Status of Esther, Ecclesiastes and the Song of Songs. Jud 44 (1), 65-79.

Clines, D J A 1990. What Does Eve do to Help? and other Readerly Questions to the Old Testament. Sheffield: Sheffield Academic Press. (JSOT suppl series 94.)

- 1994. Why is there a Song of Songs and What Does it do to You if You Read it? Jian Dao 1, 3-27.

- 1995. Interested Parties: The Ideology of Writers and Readers of the Hebrew Bible. Sheffield: Sheffield Academic Press. (JSOT suppl series 205.)

Delitzch, F 1885. The Song of Solomon. Grand Rapids: Eerdmans Publishing House. (Commentary on the $\mathrm{O} \mathrm{T}$ in 10 Volumes.)

Dennison, J T 1993. What Should I Read on the Song of Solomon? Kerux 2 (8), 35-41.

Denver, W G 1991. Women's Popular Religion Suppressed in the Bible now Revealed by Archeology. BARev 17 (2), 64-65.

Dillard, R B \& Longman III, T 1995. An Introduction to the Old Testament. Grand Rapids: Baker Book House.

Exum, J C 1973. A Literary and Structural Analysis of the Song of Songs. ZAW 85, 47 79.

Elliot, M W 1994. Ethics and Aesthetics in the Song of Songs. TB 45 (1), 137-152.

Falk, M 1990. The Song of Songs: A New Translation and Interpretation. San Francisco: Harper and Row.

Fox, M V 1985. The Song of Songs and the Ancient Egyptian Love Songs. Madison: University of Wisconsin Press. 
Gledhill, T 1994. The Message of the Song of Songs. London: IVP. (BST)

Goitein, S D 1988. Women as Creators of Biblical Genres. Proof 9, 1-33.

Goulder, M D 1986. The Song of Fourteen Songs. Sheffield: Sheffield Academic Press (JSOT suppl series 36.)

Gottwald, N K \& Horsley, R A (eds) 1993. The Bible and Liberation: Political and Social Hermeneutics. New York: Orbis Books.

Holder, J 1994. Old Testament Introduction (3). London: SPCK

Jinbachian, M M 1997. The Genre of Love Poetry in the Song of Songs and the PreIslamic Arabian Odes. BT 48 (1), 123-37.

Keane, M 1988. Feminist and Woman Theology, in Maimela, S \& König, A (eds), Initiation into Theology: The Rich Variety of Theology and Hermeneutics, 121135. Pretoria: J L van Schaik.

Kinlaw, D F 1991. The Song of Songs, in Gaebelein, F E (ed), Expositor Bible Commentary, 1201-1245. Grand Rapids: Regency Reference Library.

Lerner, G 1986. The Creation of Patriarchy. Oxford: Oxford University Press.

Lochhead, D 1993. The Liberation of the Bible, in Gottwald, N K \& Horsley, R S (eds), The Bible and Liberation: Political and Social Hermeneutics, 128-140. New York: Orbis Books.

Mariaslaven, A 1988. The Song of Songs and the Ancient Tamil Love Poems: Poetry and Symbolism. Roma: Editrice Pontificio Instituto Biblico.

Mazor, Y 1997. The Song of Songs or the Story of Stories? The Song of Songs Between Genre and Unity. SJOT 1, 1-29.

McMonagle, M X 1995. Love's Fugue: The Finest Song of All. London: Hodder and Stoughton.

Meyers, C 1978. The Roots of Restriction: Women in Early Israel. BA 6, 91-103.

Moye, J 1990. Song of Songs - Back to Allegory? Some Hermeneutical Considerations AJT 4, 120-5.

Munro, J M 1995. Spikenard and Saffron: A Study in the Poetic Language of the Song of Songs. Sheffield: Sheffield Academic Press. (JSOT suppl series 203.)

Murphy, R E 1990. The Song of Songs. Minneapolis: Fortress Press. 
Osiek, C 1985. The Feminist and the Bible: Hermeneutical Alternatives, in Collins, A Y (ed), Feminist Perspectives on Biblical Scholarship, 93-104. Chico: Scholars Press.

Payne, R 1996. The Song of Songs: Song of Woman, Song of Man, Song of God. ExpTim 107 (11), 329-333.

Pieterse, E 1996. Reflections on Postmodernism and Faith in a South African Context. JTSOA 94, 50-64.

Pilch, J J 1996. Smells and Tastes. TBT 34, 245-51.

Polaski, D C 1997. What will Ye See in the Shulammite?: Women, Power and Panopticism in the Song of Songs. Biblnt 5 (1), 64-81.

Pope, M, H 1977. The Song of Songs. New York: Doubleday. (AB 7C.)

Richardson, J P 1994. Preaching from the Song of Songs: Allegory Revisited. Churchman 108, 134-42.

Robbins, V K 1996a. The Tapestry on Early Christian Discourse: Rhetoric, Society and Ideology. New York: Routledge.

- 1996b. Exploring the Texture of Texts: A Guide to Socio-Rhetorical Interpretation. Valley Forge: Trinity Press.

Rosen, N 1996. Midrash, Bible and Women's Voices. Jud 45, 422-45.

Sakenfeld, K D 1988. Feminist Perspectives on the Bible and Theology: An Introduction to Selective Issues and Literature. Int 42 (1), 5-18.

Sasson, J M 1979. On Pope's Song of Songs. MAARAV 1 (2), 176-96.

Schneekloth, L G 1977. The Targum of the Song of Songs: A Study in the Rabinnic Interpretation. Michigan: University Microfilms International.

Schroeder, C 1996. A Love Song: Psalm 45 in the Light of the Ancient Near Eastern Marriage Texts. $C B Q 58(3), 417-32$.

Schüssler-Fiorenza, E 1983. Remembering the Past in creating the Future: HistoricalCritical Scholarship and Feminist Biblical Interpretation. SEMEIA 28, 43-63.

Stadelmann, L 1993. Love and Politic: A New Commentary on the Song of Songs. New York: Paulist Press. 
Trible, P 1987. A Daughter's Death: Feminism Criticism and the Bible, in O'Connor, M $\mathrm{P}$ \& Freedman, D N (eds), Background for the Bible, 112-143. Indiana: Eisenbrauns.

Watson, W G E 1984 [1995]. Classical Hebrew Poetry: A Guide to its Techniques. Sheffield: Sheffield Academic Press.

- 1995. Some Ancient Near Eastern Parallels to the Song of Songs, in Davies, $\mathbf{R}$ et al (eds), Words Remembered, Texts Renewed: Essays in Honour of John F A Sawyer, 253-271. Sheffield: Sheffield Academic Press. (JSOT suppl series 195.)

Webb, B G 1990. The Song of Songs: A Love Poetry as Holy Scripture. RTR 17(2), 64 65 . 